TITLE:

\title{
Neural mechanisms involved in mental imagery and observation of gait(Abstract_要旨)
}

$\operatorname{AUTHOR}(S)$ :

Iseki, Kazumi

\section{CITATION:}

Iseki, Kazumi. Neural mechanisms involved in mental imagery and observation of gait. 京 都大学, 2008, 博士(医学)

ISSUE DATE:

2008-07-23

URL:

http://hdl.handle.net/2433/124229

RIGHT: 


\begin{tabular}{|l|l|c|l|}
\hline 京都大学 & 博士 (医学) & 氏 名 & 井関 一海 \\
\hline 論文題目目 & $\begin{array}{l}\text { Neural mechanisms involved in mental imagery and observation of gait } \\
\text { (歩行運動の心的イメージと観察にかかわる神経機構) }\end{array}$ \\
\hline
\end{tabular}
(論文内容の要旨)

背景 我々の生活において歩行する際には、例えば杂倠踏の中を歩く際や人と同じ速度で歩こうとする時など に、他人の歩行を観察し自分の歩行を旨く調整することが必要なことがあり、このことから視覚情報を介し他人 の歩行運動を反映する神経系統の存在が示唆される。MRIスキャナーの中では歩行は不可能なので、健常 者において歩行計画にかかわる神経中枢を探索するために、運動実行と共通した神経回路があると考えられ る歩行運動を想像する条件を用いささら歩行に関連した動きの観察条件も使用して実験を行った。

方法 歩行に関連した 6 つの刺激1)：他人の歩行観察 2)：足踏子運動の観察 3)：静止像の観察 4): 歩行中の視覚要素に類似たた風景の観察(仮想歩行)、および視覚コントロールのために1)、4)のモザイク パターンを用意した。4)の条件では、屋内外を歩きながら簡素な背景を撮影したビデオを供覽しつつ、被験 者に自身の歩行想像を促寸ことによって、より歩行運動想像をし易くなると考えた。これらの刺激を健常人に 観察させ、脳活動を機能的MRIで測定した。得られた機能画像はSPM2にて体動補正・空間的標準化・統計 処理を行った。更に行動実験で、4)の視覚刺激補助での運動想像が実際の歩行之関連しているかを確認寸 ろため 11 人の被験者に種々の速度での4)の刺激を供覽し、想像した歩数を聞きその後実際に想像した速度 で歩かせた。

結果 行動実験では、個人レベル(R0.05)、あるいは被験者全体を対象( $P 0.01)$ とても、想像でのケイデンス (歩数/分) と実際のケイデンスが有意に相関し、4)の刺激補助での歩行の心的想像条件は、運動想像とみな すことができ、さらに実際の歩行と関連することが示された。

次に、歩行観察と心的想像のいずれの条件下でも、A)補足運動野と B)背側運動前野の活動が見られた。 そこで、それらに共通した領域を検索するため、結合解析を行ったところ、A)B)を含む領域の活動が得られ た。A)B)において歩行観察と足踏み観察による脸活動を比較したところ、歩行観察時の脳活動は足踏み観察 時の脳活動よりも有意に大きく(左内側前頭葉: $P=0.021$, 背側運動前野:右 $P=0.026$, 左 $P=0.046$ )、両者の違い が明らかとなった。

考察 行動実験で、4)の刺激を用いた歩行の心的想像は実際の歩行と運動計画機構を共有することが示唆 された。この条件では補足運動野と背側運動前野が活動を示しこれはこれまでの運動の心的想像の際の脳 活動に関する報告に合致した結果であった。

また、結合解析で活動を示した背側運動前野と補足運動野においては、歩行観察中は足踏み観察に比し 有意により大きな脳活動が得られ、歩行といら運動は単なる四肢や体幹の運動に対し特異的であるといらこと が示された。これまでの報告により、補足運動野はその障害により歩行失行等を引き起こし、特に歩行計画に 関し高次の運動制御を反映すると考えられ、背側運動前野は視覚情報のもとで歩行制御の役割を担うと推測 されている。歩行に関連した視覚情報を認知的に解釈寸る際に、視覚から運動へのプログラムが活動するも のと思われるが、我々の研究での結合解析でのこれらの領域の活動は、こういったプログラムの活動を反映し ている可能性があると考えられた。

結論 歩行の観察、心的想像両者において補足運動野と背儧運動前野の活動が得られた。れれらの領域は 歩行運動を、視覚から運動生成する際の過程にかかわるとされており、歩行の想像と歩行の観察の両者にお いて、補足運動野と背側運動前野を含む神経基盤が歩行計画にかかわる可能性があると考えられた。
（論文番査の結果の要旨）

ヒトでは歩行運動制御の調整に大脳皮質が大きくかかわる。視覚情報を介し歩行運動の相互作用を媒介 する神経機構の存在が示唆されることに着目し、歩行の想像と観察の両条件において補足運動野と背側 運動前野を含む歩行計画中枢が重要な役割を担っていることを立証した。1）他人の歩行観察２）足 踏子運動観察 3）静止像観察 4）歩行の心的想像（仮想歩行） 及び1）4）のモザイク、以上6 つの動画を供覽し、その最中の脳活動を16人の被験者においてMRIにおいて測定した。4）では、歩行想 像を容易にするべく屋内外を歩く際の背景のビデオを使用し、被験者に自身の歩行想像を促した。行動 実験では、実際の歩行と仮想歩行刺激のもとでの歩行でケイデンス（歩数/分）に相関が認められ、実 際の歩行と歩行想像に歩行の計画機構が共通寸ることが示唆された。歩行観察条件では、補足運動野、 背側運動前野、下前頭回、及び下部頭頂葉、また仮想歩行条件では、背側運動前野、補足運動野、帯状 皮質運動野、海馬傍回の活動が得られ、両者の結合解析で補足運動野と背側運動前野の活動が認められ た。これらの所見により、歩行の運動計画中枢は補足運動野と背側運動前野を含み、歩行運動の想像と 観察中に活動していることが示唆された。

以上の研究は、歩行運動にかかわる神経機構の一部を明らかにし、神経科学の発展に寄与寸るところが 多い。

したがって、本論文は博士 (医学) の学位論文として価值あるものとして認める。

なお、本学位授与申請者は、平成 20 年 5 月 28 日実施の論文内容とそれに関連した試問を受け、合格 と認められたものである 